Research Article

\title{
FACTOR INFLUENCING THE RESURGENCE OF BROWN PLANTHOPPER IN BANGLADESH
}

\author{
A.B.M.A. Uddin ${ }^{1 *}$, K.S. Islam ${ }^{2}$, M. Jahan ${ }^{2}$, A. Ara ${ }^{3}$ and M.A.I. Khan \\ ${ }^{1}$ Entomology Division, Bangladesh Rice Research Institute, Gazipur \\ ${ }^{2}$ Department of Entomology, Bangladesh Agricultural University, Mymensingh \\ ${ }^{3}$ Plant pathology Division, Bangladesh Rice Research Institute, Gazipur
}

\begin{abstract}
Possible causes of brown plant hopper resurgence were determined at the net-house of Entomology Division of Bangladesh Rice Research Institute (BRRI) during 2015. Causes of resurgence in the form of resurgence ratios were higher with acetamiprid, acephate, chlorpyrifos, cypermethrin, deltamethrin, fenvalerate, lambda cyhalothrin, thiamethoxam insecticides compared to imidacloprid, cartap, dinotefuran, isoprocarb /MIPC, phenthoate, pymetrozine when even applied at recommended dose. However, thiamethoxam, imidacloprid, isoprocarb / MIPC and cartap applied at sub-lethal dose produced higher resurgence ratio of $\mathrm{BPH}$ than others. Isoprocarb / MIPC, a commonly used recommended insecticide was found to have a higher resurgence ratio with the insecticide treatment at the egg stage (1.71) and combination of all stages (0.82). These insecticides influenced on the growth and reproductive physiology of rice brown planthopper and consequently resurgence ratio ranged increased.
\end{abstract}

Keywords: Brown planthopper, Dose, Insecticide, Resurgence, Stage

\section{INTRODUCTION}

Rice (Oryza sativa L.) is one of the world's most important crops providing a staple food for more than half of the global population (Muthayya et al., 2014). A large complex of pest organisms, consisting of insects, vertebrates, disease and weeds, have been associated with rice for hundreds of years (Islam and Catling, 2012). There are more than 232 insects (Ali et al., 2017) and several vertebrate pest species, which cause damage to the rice plants (Islam et al., 2003). Out of this large complex, about 20-30 species may be considered as the major pests and these have the potential to cause significant yield loss (Krishnaiah et al., 2008). Among the pests infesting rice, the brown planthopper (BPH), Nilaparvata lugens (Stal.) (Homoptera: Delphacidae)

\footnotetext{
*Corresponding author: masumbrri@gmail.com
} 
has gained major importance in several Asian countries including Bangladesh. The loss in grain yield ranges from 10 to $70 \%$ (Liu and Sun, 2016). It is also a vector in transmitting viral diseases such as grassy stunt, ragged stunt and wilted stunt (Cabauatan et al., 2009). In Bangladesh rice crops worth at least US\$ 8.1 million were lost due to BPH attack during the last three widespread outbreaks in 1976, 1978 and 1983 (Alam and Karim, 1986). Nowadays its outbreak is occurring frequently in different areas of Bangladesh (Ali et al., 2014), Sri Lanka (Sivasubramaniam and Imthiyas, 2018) and many other countries.

The control of this insect pest has always been emphasized and largely relied on insecticides in most rice producing countries (Ali et al., 2019) especially in countries where commercial, resistant varieties are not available. All the pesticides have different types of effect on the pest, which may lead to the differential development of the next generation of the pest (Volodymyr et al., 2018). Heavy uses of broadspectrum chemicals also reduce the biodiversity of natural enemies, lift the natural control, induce outbreak of secondary pests and contaminate ecosystem (Ali et al., 2019). Continuous use of insecticides has resulted in BPH resistance to insecticides (Wu et al., 2018) and its outbreaks.

Resurgence is one of the major causes for BPH outbreak. After application of insecticides, its resurgence was reported in Bangladesh (Alam, 2013), India (Ghosal and Chatterjee, 2018), the Philippines (Heong and Hardy, 2009) and the Poland (Wojciechowska et al., 2016). In insecticide trials in experimental stations and in farmer`s fields, hopper burn commonly occurs in treated plots while untreated areas remain relatively free of infestation (FAO, 2006). Existing literatures suggest that resurgence of BPH take place after application of some insecticides (Alam, 2013; Wojciechowska et al., 2016) that killed natural enemies (Bommarco et al., 2011) while on the other hand, it could be because of stimulated fecundity of certain pests after the applications of some insecticides (Wang et al., 2005). Improper methods of application of some insecticides also caused resurgence. To find out the reasons for resurgence of $\mathrm{BPH}$, an experiment was planned, designed and conducted in the net house conditions.

\section{MATERIALS AND METHODS}

The trial was conducted at entomology net house of Bangladesh Rice Research Institute during 2015. The trial cage consisted of a steel frame covered with fine mesh wire screen. The size of the cage was $152 \times 66 \times 84 \mathrm{~cm}$. It consisted of three chambers. The size of each chamber was $51 \times 65 \times 84 \mathrm{~cm}$. The cage bottom was open and placed on a tray made of steel $(183 \times 91 \times 15 \mathrm{~cm})$. Standing water was maintained in the tray. The tray with cage was placed in an iron frame $(183 \times 76 \times 76$ $\mathrm{cm})$. Twenty-five to 30 -day-old plants were used as experimental units. Each pot contained three hills and the number of tillers per pot ranged from 40-50. The plants in the pot were cleaned by removing dried, diseased and insect infested leaves. 
Before imposing treatments, it was also confirmed that plants were free from eggs of any insects. Each pot was covered by Mylar cage of height $76.2 \mathrm{~cm}$ and diameter $50.4 \mathrm{~cm}$. Ten gravid BPH female were introduced in each Mylar cage followed by closing the top with net. The gravid female within the pots were allowed to lay egg for 48 hours. Egg bearing pot was kept in chamber. Three pots were introduced in each chamber, which was considered as a replication. In all growth stages, BPH were collected from rearing chamber and released into experiment chamber (ca. 100/pot). Burned tillers bearing pots were replaced by fresh tiller bearing pots during study period as and when necessary. The partition of each chamber was covered by thick polythene sheet in order to keep the original condition of each chamber. This experiment was laid out in a Randomized Complete Block Design (RCBD) with three replications. Each chamber with three pots was considered as one replication of a treatment, and each room treated as one block.

\section{Effect of different insecticides on the development of BPH resurgence}

Fourteen groups of single molecule containing chemical insecticides were applied at recommended dose (Table 1). Fresh water was applied on the plants of control treatments. Hand sprayer (Seesa hand pressure sprayer) was used to spray insecticide.

Table 1. Name of the insecticides with concentration used in the treatments

\begin{tabular}{clc}
\hline Treatment & Name of insecticide & $\begin{array}{c}\text { Recommended dose } \\
(\mathrm{g} \text { or ml/L water) }\end{array}$ \\
\hline $\mathrm{T}_{1}$ & Acetamiprid (Tundra 20 SP) & $0.25 \mathrm{~g}$ \\
$\mathrm{~T}_{2}$ & Acephate (Mimpahte 75 SP) & $1.50 \mathrm{~g}$ \\
$\mathrm{~T}_{3}$ & Imidacloprid (Admire 20 SL) & $0.25 \mathrm{ml}$ \\
$\mathrm{T}_{4}$ & Cartap (Suntap 50 SP) & $2.40 \mathrm{~g}$ \\
$\mathrm{~T}_{5}$ & Chlorpyrifos (Dursban 20 EC) & $2.00 \mathrm{ml}$ \\
$\mathrm{T}_{6}$ & Cypermethrin (Cymbaz 10 EC) & $1.00 \mathrm{ml}$ \\
$\mathrm{T}_{7}$ & Deltamethrin (Decis 2.5 EC) & $1.00 \mathrm{ml}$ \\
$\mathrm{T}_{8}$ & Dinotefuran (Token 20SG) & $0.30 \mathrm{~g}$ \\
$\mathrm{~T}_{9}$ & Fenvalerate (Fenfen 20 EC) & $0.50 \mathrm{ml}$ \\
$\mathrm{T}_{10}$ & Isoprocarb/MIPC (Chabi 75 WP) & $2.60 \mathrm{~g}$ \\
$\mathrm{~T}_{11}$ & Lambda cyhalothrin (Karate 2.5 EC) & $1.00 \mathrm{ml}$ \\
$\mathrm{T}_{12}$ & Phenthoate (Kiron 50 EC) & $2.00 \mathrm{ml}$ \\
$\mathrm{T}_{13}$ & Pymetrozine (Plenum 50 WG) & $0.60 \mathrm{~g}$ \\
$\mathrm{~T}_{14}$ & Thiamethoxam (Spike 25 WG) & $0.12 \mathrm{~g}$ \\
$\mathrm{~T}_{15}$ & Control & Only water \\
\hline
\end{tabular}




\section{Effect of different doses of selected insecticides on resurgence development}

Three doses viz. lower, recommended and higher dose of five selected insecticides were sprayed in an experimental arena as treatment with the help of a hand sprayer. A control experimental site was also maintained which was sprayed with fresh water only (Table 2 ).

Table 2. Name of the treatments of insecticides with different doses

\begin{tabular}{clc}
\hline Treatment & Insecticide & $\begin{array}{c}\text { Low, recommended and } \\
\text { higher dose } \\
\text { (g or ml/L water) }\end{array}$ \\
\hline $\mathrm{T}_{1}$ & Imidacloprid (Admire 20 SL) & $0.20 \mathrm{ml}$ \\
$\mathrm{T}_{2}$ & Imidacloprid (Admire 20 SL) & $0.25 \mathrm{ml}$ \\
$\mathrm{T}_{3}$ & Imidacloprid (Admire 20 SL) & $0.30 \mathrm{ml}$ \\
$\mathrm{T}_{4}$ & Cartap (Suntap 50 SP) & $2.20 \mathrm{~g}$ \\
$\mathrm{~T}_{5}$ & Cartap (Suntap 50 SP) & $2.40 \mathrm{~g}$ \\
$\mathrm{~T}_{6}$ & Cartap (Suntap 50 SP) & $2.80 \mathrm{~g}$ \\
$\mathrm{~T}_{7}$ & Isoprocarb/MIPC (Chabi 75 WP) & $2.20 \mathrm{~g}$ \\
$\mathrm{~T}_{8}$ & Isoprocarb/MIPC (Chabi 75 WP) & $2.60 \mathrm{~g}$ \\
$\mathrm{~T}_{9}$ & Isoprocarb/MIPC (Chabi 75 WP) & $2.80 \mathrm{~g}$ \\
$\mathrm{~T}_{10}$ & Pymetrozine (Plenum 50 WG) & $0.30 \mathrm{~g}$ \\
$\mathrm{~T}_{11}$ & Pymetrozine (Plenum 50 WG) & $0.60 \mathrm{~g}$ \\
$\mathrm{~T}_{12}$ & Pymetrozine (Plenum 50 WG) & $0.90 \mathrm{~g}$ \\
$\mathrm{~T}_{13}$ & Thiamethoxam (Spike 25 WG) & $0.10 \mathrm{~g}$ \\
$\mathrm{~T}_{14}$ & Thiamethoxam (Spike 25 WG) & $0.12 \mathrm{~g}$ \\
$\mathrm{~T}_{15}$ & Thiamethoxam (Spike 25 WG) & $0.14 \mathrm{~g}$ \\
$\mathrm{~T}_{16}$ & Control & Only water \\
\hline
\end{tabular}

Effect of insecticides on different stages of BPH for the possible resurgence development

Different stages of BPH, such as $\mathrm{T}_{1}=$ egg, $\mathrm{T}_{2}=1^{\text {st }}-2^{\text {nd }}$ instar nymph, $\mathrm{T}_{3}=3^{\text {rd }}-4^{\text {th }}$ instar nymph, $\mathrm{T}_{4}=$ adult and $\mathrm{T}_{5}=$ combination of all stages was used as the treatment. Specific arena was developed according to treatment. A control chamber $\left(\mathrm{T}_{6}\right)$ was also maintained consisting all growth stages of BPH. Isoprocarb / MIPC insecticide (Chabi $75 \mathrm{WP}$ ) was applied in each chamber at the rate of $2.6 \mathrm{~g} / \mathrm{L}$ of water. The control chamber was sprayed with fresh water.

Data Collection: The BPH populations were recorded before imposing treatments through counting. The BPH populations were recorded after 72 hours and 30 days of 
spraying. The resurgence ratio of $\mathrm{BPH}$ was calculated by the following equation (Heinrichs et al., 1981):

Population after application of insecticide

Resurgence ratio $=$

Population in check field at the same interval

Statistical analysis: The collected data were arranged as required for statistical analysis. The software program STATISTIX 10 was selected to analysis the data as it is reported to be more efficient in analyzing entomological data. The mean differences among the treatments were determined by LSD test.

\section{RESULTS AND DISCUSSION}

\section{Effect of different insecticides on the development of $\mathrm{BPH}$ resurgence}

The number of BPH/pot was not significantly different among the treatments before insecticide spray (Table 3), although it varied significantly after 72 hours and one month of spraying. The data of table 3 clearly showed that the resurgence ratio was significantly higher in $\mathrm{T}_{6}(2.06)$ followed by $\mathrm{T}_{7}, \mathrm{~T}_{1}, \mathrm{~T}_{11}$ and $\mathrm{T}_{9}$. Moderate resurgence ratio was found in $\mathrm{T}_{14}(1.07)$ and it was not significantly different with resurgence ratio of $T_{2}$ (1.03) and $T_{5}(1.02)$. The lowest resurgence ratio was found in $T_{8}$ and $T_{13}$ (0.25 to 0.26$)$ followed by $\mathrm{T}_{12}(0.71), \mathrm{T}_{4}(0.82), \mathrm{T}_{10}(0.83)$ and $\mathrm{T}_{3}(0.96) . \mathrm{T}_{8}$ and $\mathrm{T}_{13}$ were almost identical and $\mathrm{T}_{4}, \mathrm{~T}_{10}$ were not significantly different among them.

Table 3. Effect of single molecule containing insecticides on resurgence development

\begin{tabular}{|c|c|c|c|c|c|c|}
\hline & & \multicolumn{4}{|c|}{$\begin{array}{l}\text { No. of BPH/pot at different time } \\
\text { intervals }\end{array}$} & \multirow{2}{*}{$\begin{array}{l}\text { Resurgenc } \\
\text { e ratio }\end{array}$} \\
\hline \multicolumn{2}{|c|}{ Treatment } & \multirow{2}{*}{$\begin{array}{c}\text { dose }(\mathrm{g} \text { or } \mathrm{ml} / \mathrm{L} \\
\text { water }) \\
0.25 \mathrm{~g}\end{array}$} & \multirow{2}{*}{$\begin{array}{c}\begin{array}{c}\text { Before spray } \\
\text { (pretreatment) }\end{array} \\
109.33 \mathrm{a}\end{array}$} & \multirow{2}{*}{$\begin{array}{c}\begin{array}{c}\text { After } 72 \\
\text { hours of } \\
\text { spray }\end{array} \\
50.00 \mathrm{~b}\end{array}$} & \multirow{2}{*}{$\begin{array}{c}\begin{array}{c}\text { After one } \\
\text { month of } \\
\text { spray }\end{array} \\
212.67 \mathrm{bc}\end{array}$} & \\
\hline $\mathrm{T}_{1}$ & $\begin{array}{l}\text { Acetamiprid } \\
\text { (Tundra } 20 \mathrm{SP} \text { ) }\end{array}$ & & & & & $1.38 \mathrm{bc}$ \\
\hline $\mathrm{T}_{2}$ & $\begin{array}{l}\text { Acephate } \\
\text { (Mimpahte } 75 \text { SP) }\end{array}$ & $1.50 \mathrm{~g}$ & $109.33 \mathrm{a}$ & $17.33 \mathrm{f}$ & $159.00 \mathrm{de}$ & $1.03 \mathrm{~d}$ \\
\hline $\mathrm{T}_{3}$ & $\begin{array}{l}\text { Imidacloprid } \\
\text { (Admire } 20 \mathrm{SL} \text { ) }\end{array}$ & $0.25 \mathrm{ml}$ & $110.67 \mathrm{a}$ & 37.00 & $149.00 \mathrm{f}$ & $0.96 \mathrm{e}$ \\
\hline $\mathrm{T}_{4}$ & $\begin{array}{l}\text { Cartap } \\
\text { (Suntap } 50 \mathrm{SP})\end{array}$ & $2.40 \mathrm{~g}$ & $110.33 \mathrm{a}$ & $10.67 \mathrm{~g}$ & $126.67 \mathrm{~g}$ & $0.82 \mathrm{f}$ \\
\hline $\mathrm{T}_{5}$ & $\begin{array}{l}\text { Chlorpyrifos } \\
\text { (Dursban } 20 \mathrm{EC} \text { ) }\end{array}$ & $2.00 \mathrm{ml}$ & $110.33 \mathrm{a}$ & $10.67 \mathrm{~g}$ & $157.33 \mathrm{e}$ & $1.02 \mathrm{~d}$ \\
\hline $\mathrm{T}_{6}$ & $\begin{array}{l}\text { Cypermethrin } \\
\text { (Cymbaz } 10 \mathrm{EC})\end{array}$ & $1.00 \mathrm{ml}$ & $109.67 \mathrm{a}$ & $49.00 \mathrm{~b}$ & $318.33 \mathrm{a}$ & $2.06 \mathrm{a}$ \\
\hline
\end{tabular}




\begin{tabular}{|c|c|c|c|c|c|c|}
\hline \multirow{2}{*}{\multicolumn{2}{|c|}{ Treatment }} & \multirow{2}{*}{$\begin{array}{l}\text { Recommended } \\
\text { dose (g or } \mathrm{ml} / \mathrm{L} \\
\text { water) }\end{array}$} & \multicolumn{3}{|c|}{$\begin{array}{l}\text { No. of BPH/pot at different time } \\
\text { intervals }\end{array}$} & \multirow{2}{*}{$\begin{array}{l}\text { Resurgenc } \\
\text { e ratio }\end{array}$} \\
\hline & & & \multirow{2}{*}{$\begin{array}{c}\begin{array}{l}\text { Before spray } \\
\text { (pretreatment) }\end{array} \\
109.67 \mathrm{a}\end{array}$} & \multirow{2}{*}{$\begin{array}{c}\begin{array}{c}\text { After } 72 \\
\text { hours of } \\
\text { spray }\end{array} \\
48.00 \mathrm{~b}\end{array}$} & \multirow{2}{*}{$\begin{array}{c}\begin{array}{c}\text { After one } \\
\text { month of } \\
\text { spray }\end{array} \\
215.67 \mathrm{~b}\end{array}$} & \\
\hline $\mathrm{T}_{7}$ & $\begin{array}{l}\text { Deltamethrin } \\
\text { (Decis } 2.5 \mathrm{EC} \text { ) }\end{array}$ & $1.00 \mathrm{ml}$ & & & & $1.40 \mathrm{~b}$ \\
\hline $\mathrm{T}_{8}$ & $\begin{array}{l}\text { Dinotefuran } \\
\text { (Token 20SG) }\end{array}$ & $0.30 \mathrm{~g}$ & $110.00 \mathrm{a}$ & $3.00 \mathrm{i}$ & $39.00 \mathrm{i}$ & $0.25 \mathrm{~h}$ \\
\hline $\mathrm{T}_{9}$ & $\begin{array}{l}\text { Fenvalerate } \\
\text { (Fenfen } 20 \text { EC) }\end{array}$ & $0.50 \mathrm{ml}$ & $109.33 \mathrm{a}$ & $79.00 \mathrm{a}$ & $206.67 \mathrm{c}$ & $1.34 \mathrm{c}$ \\
\hline $\mathrm{T}_{10}$ & $\begin{array}{l}\text { Isoprocarb/MIPC } \\
\text { (Chabi } 75 \mathrm{WP} \text { ) }\end{array}$ & $2.60 \mathrm{~g}$ & $110.00 \mathrm{a}$ & $10.67 \mathrm{~g}$ & $129.00 \mathrm{~g}$ & $0.83 \mathrm{f}$ \\
\hline $\mathrm{T}_{11}$ & $\begin{array}{l}\text { Lambda } \\
\text { cyhalothrin } \\
\text { (Karate } 2.5 \mathrm{EC} \text { ) }\end{array}$ & $1.00 \mathrm{ml}$ & $111.33 \mathrm{a}$ & $25.67 \mathrm{e}$ & $210.00 \mathrm{bc}$ & $1.36 \mathrm{bc}$ \\
\hline $\mathrm{T}_{12}$ & $\begin{array}{l}\text { Phenthoate } \\
\text { (Kiron } 50 \mathrm{EC} \text { ) }\end{array}$ & $2.00 \mathrm{ml}$ & $108.00 \mathrm{a}$ & $17.33 \mathrm{f}$ & $109.33 \mathrm{~h}$ & $0.71 \mathrm{~g}$ \\
\hline $\mathrm{T}_{13}$ & $\begin{array}{l}\text { Pymetrozine } \\
\text { (Plenum } 50 \mathrm{WG} \text { ) }\end{array}$ & $0.60 \mathrm{~g}$ & $109.67 \mathrm{a}$ & $6.67 \mathrm{~h}$ & $40.00 \mathrm{i}$ & $0.26 \mathrm{~h}$ \\
\hline $\mathrm{T}_{14}$ & $\begin{array}{l}\text { Thiamethoxam } \\
\text { (Spike 25 WG) }\end{array}$ & $0.12 \mathrm{~g}$ & $107.67 \mathrm{a}$ & $32.00 \mathrm{~d}$ & $165.00 \mathrm{~d}$ & $1.07 \mathrm{~d}$ \\
\hline $\mathrm{T}_{15}$ & Control & Only water & $108.00 \mathrm{a}$ & $79.67 \mathrm{a}$ & $154.67 \mathrm{ef}$ & - \\
\hline \multicolumn{2}{|c|}{ Level of significance } & & NS & $* *$ & $* *$ & $* *$ \\
\hline \multicolumn{2}{|c|}{$\mathrm{LSD}_{0.05}$} & & 9.92 & 3.29 & 6.98 & 0.05 \\
\hline \multicolumn{2}{|c|}{$\mathrm{CV} \%$} & & 5.41 & 6.19 & 2.62 & 2.97 \\
\hline
\end{tabular}

$* *=$ Significant at $1 \%$ level of probability, $*=$ Significant at $5 \%$ level of probability

NS= Non-Significant, Values in a column followed by different letters are significantly different

With increased adoption of new high yielding varieties, use of insecticides were also increased and the destruction of predators and parasitoids that followed insecticide misuse resulted in resurgence of several rice pests including the BPH, Nilaparvata lugens (Heinrichs and Mochida, 1984). Anand et al. (2019) conducted an experiment with seven insecticides viz., chlorpyriphos, profenophos, cypermethrin, deltamethrin, bifenthrin, lambda cyhalothrin and imidacloprid on the growth and reproductive physiology of rice brown planthopper. They reported that bifenthrin, cypermethrin, lambda cyhalothrin and deltamethrin resulted in enhancement of fecundity of brown planthopper (227.67, 218.33, 199.00 and 191.00 nymph's vs. 131.00 nymphs in control) and consequently resurgence ratio ranged from 1.18 to 1.74 . Chlorpyriphos, cypermethrin, deltamethrin, bifenthrin and lambda cyhalothrin also significantly 
increased the nymphal survival ( 86.67 per cent to 96.00 per cent against 80.67 per cent in control) and growth index (6.34 to 7.11 vs 5.63 in control).

\section{Effect of different doses of selected insecticides on development of BPH resurgence}

The data clearly showed that the number of BPH/pot was not significantly different (104 to 107) among the treatment before spray (Table 4) that differed significantly after $72 \mathrm{~h}$ and one month of spraying. The resurgence ratio was highest in $\mathrm{T}_{13}$ (1.61) followed by $T_{1}$ (1.39) and then $T_{14}$ (1.30), $T_{7}$ (1.26) and $T_{4}$ (1.22). $T_{13}$ was significantly different with other treatments but $\mathrm{T}_{14}$ and $\mathrm{T}_{7}$ were insignificant. Resurgence ratio in $\mathrm{T}_{15}, \mathrm{~T}_{10}, \mathrm{~T}_{2}, \mathrm{~T}_{9}, \mathrm{~T}_{3}$ and $\mathrm{T}_{5}$ were $1.08,1.02,0.98,0.97,0.92,0.91$ and 0.91 , respectively. Significantly the lowest resurgence ratio was found in $\mathrm{T}_{12}$ $(0.65)$ and $\mathrm{T}_{11}(0.69)$ followed by $\mathrm{T}_{6}(0.84)$. $\mathrm{T}_{12}$ and $\mathrm{T}_{11}$ were insignificantly different among them but significantly different with $\mathrm{T}_{6}$.

Use of insecticide at lower dose is common in farmers' practice as it saves some money apparently. The practice of using low dose combined with short residual toxicity of many commercial insecticides may often cause the sub-lethal effect to the pest. The result is in conformity with the earlier findings (Heinrichs et al., 1982; Chelliah and Uthamasamy, 1986; Karns and Stewart, 2003. Heinrichs et al. 1982) and reported high BPH populations (40-fold) with lower application rates of FMC 3500 (0.2 kg a.i./ha) as compared to high rate (1.0 kg a.i./ha). Chelliah (1979) reported that low doses of resurgence-inducing insecticides increased the reproductive rate of the $\mathrm{BPH}$ and reduced the nymphal duration, eventually leading to resurgence. Heinrichs and Mochida (1984) reported that dose rates had a distinct effect on the degree of resurgence in both the decamethrin and methyl parathion treatments with the higher rates permitting the higher BPH populations. There were $850 \mathrm{BPH}$ per hill at the high and $210 \mathrm{BPH}$ per hill at the low decamethrin rate and 60 BPH per hill in the check. Present findings showed 20-50\% increase in the levels of resurgence when low dose was used. Further lower dose might increase the resurgence ratio to some higher degree. The efficacy study of isoprocarb/MIPC showed it was an effective insecticide but when applied with sub-lethal dose was found to be developed resurgence. It clearly indicates that any recommended product or chemical could also be cause of resurgence development under improper doses. Bao et al. (2009) conducted an experiment on the effects of sublethal doses of four insecticides viz. triazophos, fenvalerate, imidacloprid and dinotefuran on the reproduction of $\mathrm{BPH}$. Imidacloprid and dinotefuran reduced the fecundity of BPH to $68.8 \%$ and $52.4 \%$ in macropterous families, and to $57.9 \%$ and $43.1 \%$ in brachypterous families, when compared with the untreated controls. By contrast, triazophos and fenvalerate increased fecundity and consequently resurgence ratio increased. 
Table 4. Effect of different doses of selected insecticides on resurgence development



$* *=$ Significant at $1 \%$ level of probability, $*=$ Significant at $5 \%$ level of probability

NS= Non-Significant, Values in a column followed by different letters are significantly different 


\section{Effect of insecticide on different stages of BPH for the development of resurgence}

Five different growth stages including combination of all stages were sprayed with a most common insecticide - Isoprocarb/MIPC (Chabi 75 WP) for the development of resurgence (Table 5). In treatment $\mathrm{T}_{1}$, the number of $\mathrm{BPH} /$ pot was nil (only bearing eggs) and there was no significant difference among the treatments $\left(\mathrm{T}_{2}\right.$ to $\left.\mathrm{T}_{6}\right)$ before insecticide application. After 72 hours of spraying, significantly the highest number of $\mathrm{BPH}$ was found in control treatment; but after one month it was significantly higher with $T_{1}$ (303) followed by $T_{6}$ (178). Zero population was found in $T_{2}$ and $T_{3}$ treatments. Resurgence ratio was also significantly higher in $T_{1}$ (1.71) treatment compared to other treatments. But no significant difference was found between $\mathrm{T}_{4}$ $(0.78)$ and $\mathrm{T}_{5}(0.82)$ treatments.

Table 5. Effect of isoprocarb/MIPC (Chabi $75 \mathrm{WP}$ ) on different stage of brown planthopper for the development of resurgence

\begin{tabular}{|c|c|c|c|c|c|}
\hline \multirow{2}{*}{\multicolumn{2}{|c|}{ Treatment }} & \multicolumn{3}{|c|}{ No. of BPH/pot at different time intervals } & \multirow{3}{*}{$\begin{array}{l}\text { Resurgence } \\
\text { ratio }\end{array}$} \\
\hline & & Before spray & After 72 & After one & \\
\hline $\mathrm{T}_{1}$ & Egg & $0.00 \mathrm{~b}$ & $0.00 \mathrm{~d}$ & $303.00 \mathrm{a}$ & \\
\hline $\mathrm{T}_{2}$ & $1^{\text {st }}-2^{\text {nd }}$ instar nymph & $97.00 \mathrm{a}$ & $1.67 \mathrm{~cd}$ & $0.00 \mathrm{~d}$ & $0.00 \mathrm{c}$ \\
\hline $\mathrm{T}_{3}$ & $3^{\text {rd }}-4^{\text {th }}$ instar nymph & $100.00 \mathrm{a}$ & $5.00 \mathrm{c}$ & $0.00 \mathrm{~d}$ & $0.00 \mathrm{c}$ \\
\hline $\mathrm{T}_{4}$ & Adult & $98.67 \mathrm{a}$ & $15.67 \mathrm{~b}$ & $138.00 \mathrm{c}$ & $0.78 b$ \\
\hline $\mathrm{T}_{5}$ & $\begin{array}{l}\text { Combination of all } \\
\text { stages }\end{array}$ & $100.00 \mathrm{a}$ & $19.00 \mathrm{~b}$ & $144.44 \mathrm{c}$ & $0.82 b$ \\
\hline $\mathrm{T}_{6}$ & $\begin{array}{l}\text { Combination of all } \\
\text { stages (control) }\end{array}$ & $99.67 \mathrm{a}$ & $84.33 \mathrm{a}$ & $177.67 \mathrm{~b}$ & - \\
\hline \multicolumn{2}{|c|}{ Level of significance } & $* *$ & $* *$ & $* *$ & $* *$ \\
\hline \multicolumn{2}{|c|}{$\mathrm{LSD}_{0.05}$} & 4.97 & 4.99 & 24.30 & 0.19 \\
\hline \multicolumn{2}{|c|}{ CV\% } & 3.31 & 13.09 & 10.5 & 15.4 \\
\hline
\end{tabular}

$* *=$ Significant at $1 \%$ level of probability, *= Significant at $5 \%$ level of probability

NS= Non-Significant, Values in a column followed by different letters are significantly different

Many researchers reported that the effectiveness of insecticide depends on the stage of the insect. The reproductive rates of BPH exposed to insecticide-sprayed plants during nymphal or adult stage or both varied significantly (Chelliah, 1979). The reproductive rate was significantly higher when the BPH was exposed to plants sprayed with resurgence-inducing insecticides at the fourth-and fifth-instar stage as well as the adult stage (Chelliah, 1979). The result of the present study clearly showed that the nymph of the BPH was more susceptible to insecticides than the egg 
and adult stages. Therefore, care should be taken to apply insecticides depending on stage of the pest. There may be a requirement to spray the crop again after a few days to kill the early insects of pest developed from the primary sprayed egg.

\section{CONCLUSION}

The insecticide namely acetamiprid, acephate, chlorpyrifos, cypermethrin, deltamethrin, fenvalerate, lambda-cyhalothrin, thiamethoxam were responsible for higher resurgence of BPH. In contrast, imidacloprid, cartap, dinotefuran, isoprocarb/MIPC, phenthoate, pymetrozine showed low resurgence producing potentials. So, recommendation of insecticides for controlling BPH that produce low resurgence require special attention in selecting right dose at the right time because they may cause high resurgence of BPH when used at sub-lethal dose. A similar high resurgence was evident with insecticide treatment at egg and adult stage. There may be a requirement to spray the crop again after a few days to kill the early insects of pest developed from the primary sprayed egg.

\section{REFERENCES}

Alam, M.Z. (2013). Survey and assessment of insect management technologies and environmental impact on rice ecosystem of Bangladesh. International Journal of Applied Research and Studies, 2(4): 1-16.

Alam, S. and Karim, A.N.M.R. (1986). Brown planthopper situation and its management in Bangladesh. Proceedings of the Workshop on Experiences with Modern Rice Cultivation in Bangladesh, 8-11 April 1984. Bangladesh Rice Research Institute, Gazipur, Bangladesh. Pp. 10-29.

Ali, M.P., Bari, M.N., Ahmed, N., Kabir, M.M.M., Afrin, S., Zaman, M.A.U., Haque, S.S. and Willers, J.L. (2017). Rice production without insecticide in smallholder farmer's field. Frontiers in Environmental Science, 5:16.

Ali, M.P., Bari, M.N., Haque, S.S., Kabir, M.M.M., Afrin, S., Nowrin, F., Islam, M.S. and Landis, D.A. (2019). Establishing next-generation pest control services in rice fields: eco-agriculture. Scientific Reports, 9(1):1-9.

Ali, M.P., Huang, D., Nachman, G., Ahmed, N., Begum, M.A. and Rabbi, M.F. (2014). Will Climate change affect outbreak patterns of planthoppers in Bangladesh? Plos One, 9(3): 1-10.

Anand, K. A., Rama, R. CV., Mallikharjuna, R. N., Krishnam, R. S. and Nafeez, U. SK. (2019). Influence of certain insecticides on the resurgence of rice brown planthopper, Nilaparvata lugens (Stal). Journal of Entomology and Zoology Studies, 7(3): 874-878.

Bao, H., Liu, S., Gu, J., Wang, X., Liang, X. and Liu. Z. (2009). Sublethal effects of four insecticides on the reproduction and wing formation of brown planthopper, Nilaparvata lugens. Pest Management Science 65(2):170-174.

Bommarco, R., Miranda, F., Bylund, H. and Rkman, C.B. (2011). Insecticides suppress natural enemies and increase pest damage in cabbage. Journal of Economic Entomology, 104(3): 782-791. 
Cabauatan, P.Q, Cabunagan, R.C. and Choi, I. (2009). Rice viruses transmitted by the brown planthopper Nilaparvata lugens Stål. In Heong, K.L. and Hardy, B. (Eds.). Planthoppers: New threats to the sustainability to of intensive rice production systems in Asia. International Rice Research Institute, Pp.357-368.

Chelliah, S. (1979). Insecticide application and brown planthopper, Nilaparvata lugens (Stål) resurgence in rice. A report of research conducted from July 8, 1977 to July 7, 1979. Department of Entomology, International Rice Research Institute, Los Baños, Philippines. Pp. 69.

Chelliah, S. and Uthamasamy, S. (1986). Insecticide induced resurgence of insect pests of rice. Oryza. 23: 71-82.

FAO. (2006). International code of conduct on the distribution and use of pesticides Guidelines on efficacy evaluation for the registration of plant protection products. Rome. Pp. 61.

Gao, C.X., Gu, X.H. and Bei, Y.W. (1988). A study on the cause of resurgence of brown planthopper. Acta Ecologica Sinica, 8: 155-163.

Ghosal, A. and Chatterjee, M. (2018). Insecticide induced resurgence study of whitefly in cotton and tomato. University of Sindh Journal of Animal Sciences, 2(2): 1-6.

Heinrichs, E.A. and Medrano, F.G. (1984). Leersia hexadra, a weed host of the brown planthopper, Nilaparvata lugens (Stal). Crop Protection, 3:77-85.

Heinrichs, E.A., Chelliah, S., Valencia, S.L., Arceo, M.B., Fabellar, L.T. and Aquino, G.B. (1981). Manual for testing insecticides on rice. International Rice Research Institute, Los Banos, Laguan, Philippines. Pp. 134.

Heinrichs, E.A., Reissig, W.H., Valencia, S.L. and Chelliah, S. (1982). Rates and effect of resurgence-induced insecticides on populations of Nilaparvata lugens (Stål) (Homoptera: Delphacidae) and its predators. Environmental Entomology, 11: 12671273.

Heong, K.L. and Hardy, B. (2009). Planthoppers: new threats to the sustainability of intensive rice production systems in Asia. International Rice Research Institute, Los Baños, Philippines. Pp. 157-1783.

Islam, Z. and Catling, D. (2012). Rice pest of Bangladesh: Their ecology and management. The University Press Limited, Dhaka, Bangladesh. Pp. 320.

Islam, Z., Rahman, M.A., Barrion, A.T., Polaszek, A., Chancellor, T., Heong, K.L., Ahmed, N., Haq, M. and Kamal, N.Q. (2003). Diversity of Arthropods in irrigated rice in Bangladesh. Bangladesh Journal of Entomology, 13(2): 1-25.

Karns, D.L. and Stewart, S.D. (2003). Sub-lethal effects of insecticides on the intrinsic rate of increase of cotton aphid. Entomologia Experimentalis et Applicata, 94(1): 41-49.

Krishnaiah, N.V., Lakshmi, V.J., Pasalu, I.C., Katti, G.R. and Padmavathi, C. (2008). Insecticides in rice IPM-Past, present and future. Hyderabad (India): Directorate of Rice Research, ICAR. Pp. 148.

Liu, X. and Sun, Q. (2016). Early assessment of the yield loss in rice due to the brown planthopper using a hyperspectral remote sensing method. International Journal of Pest Management, 62 (3): 205-213. 
Muthayya, S., Sugimoto, J.D., Montgomery, S. and Maberly, G. (2014). An overview of global rice production, supply, trade, and consumption. Annals of the New York Academy of Sciences, 1324: 7-14.

Sivasubramaniam, N. and Imthiyas, M.S.M. (2018). Evaluation of the major factors associated in controlling of brown planthopper (Nilaparvata lugens) in paddy cultivation during its outbreak in selected divisional secretariats of the Ampara District of Sri Lanka. Scholars Journal of Agriculture and Veterinary Sciences, 5(11): 595-600.

Volodymyr, I.L., Tetiana, M.M., Viktor, V.H., Janet, M.S. and Kenneth. B.S. (2018). Pesticide toxicity: a mechanistic approach. EXCLI Journal, 17: 1101-1136.

Wang, A.H., Wu, J.C., Yu, Y.S., Liu, J.L., Yue, J.F. and Wang, M.Y. (2005). Selective Insecticide-Induced Stimulation on Fecundity and Biochemical Changes in Tryporyza incertulas (Lepidoptera: Pyralidae). Journal of Economic Entomology, 98(4):1144-9.

Wojciechowska, M., Stepnowski, P. and Gołębiowski, M. (2016). The use of insecticides to control insect pests. Information Systems Journal, 13: 210-220.

Wu, S., Zeng, B., Zheng, C., Mu, X., Zhang, Y., Hu, J., Zhang, S., Gao, C. and Shen, J. (2018). The evolution of insecticide resistance in the brown planthopper (Nilaparvata lugens Stål) of China in the period 2012-2016. Scientific Report, 8(1): 1-11. 